\section{Anti-tuberculosis effects of different medicinal plants: A narrative review}

\author{
Amjad Hussain ${ }^{1 *}$, Aadil Ameer Ali², Sultan $\mathrm{Ayaz}^{3}$, \\ Wahidullah", Pervez Mehar ${ }^{5}$, Ahmad Ali ${ }^{5}$, Zakir Ullah ${ }^{5}$ and \\ Ramsha Baig'
}

${ }^{1}$ Lecturer, Department of Eastern Medicine, Faculty of Pharmacy and Health Sciences, University of Balochistan Quetta, Pakistan

Institute of Physiotherapy \& Rehabilitation Sciences, Shaheed Mohtarma Benazir Bhutto Medical University, Larkana, Pakistan

${ }^{3}$ Department of Eastern Medicine, Government College University, Faisalabad, Pakistan

${ }^{4}$ Wilson Pharmaceuticals, Islamabad, Pakistan

${ }^{5}$ Faculty of pharmacy, Gomal University, Dera Ismail khan, Pakistan
Received: 29 August, 2021

Accepted: 30 September, 2021

Published: 01 October, 2021

*Corresponding author: Amjad Hussain, Lecturer, Department of Eastern Medicine, Faculty of Pharmacy and Health Sciences, University of Balochistan Quetta, Pakistan, Email: aadilamirali@hotmail.com

Keywords: Medicinal plants; Phytochemicals; Tuberculosis; Toxicological effects

Copyright: (C 2021 Hussain A, et al. This is an openaccess article distributed under the terms of the Creative Commons Attribution License, which permits unrestricted use, distribution, and reproduction in any medium, provided the original author and source are credited.

https://www.peertechzpublications.com

Check for updates

\begin{abstract}
The medicinal plants contain various chemical constituents which play an important role in the treatment of various diseases. The current review explained the scattered information on medicinal plants used in the treatment of tuberculosis. The review contains four medicinal plants (Allium sativum ( $L$ ), Aloe vera ( $L$ ), Acalypha indica $(L)$ and Allium cepa $(L))$ having anti-tubeculosis effects. Moreover, six medicinal plants (Acorus calamus $(L)$, Curcuma longa $(L)$, Ephedra gerardiana, Glycyrrhiza glabra (L), Hygrophila auriculata, Papaver somniferum $(L))$ have been checked for their toxicological impacts in the treatment of tuberculosis.
\end{abstract}

\section{Introduction}

Mycobacterium Tuberculosis (MBT) is a pathogenic bacteria which causes tuberculosisPrimarily it effects the respiratory system but it may effects the other systems like urogenital system (painless hematuria (it would be painful if the clots occurred), hematospermia, Gastrointestinal system (abdominal pain and intestinal obstruction [1-6].The signs and symptoms of tuberculosis are cough, fever, night sweating, haemoptysis, dyspnoea, tachycardia, anaemia, chest pain and weight loss [4]. In the developing countries, tuberculosis is a dreadful infection. Annually It infects almost 9 million people, more than 2 million deaths occur annually due to this infection $[7,8]$. The deaths may be increase in the future because of increase spread of multidrug-resistant bacterial strains [9]. Furthermore human immunodeficiency virus is another risk factor which has significantly increased the new cases of tuberculosis [10-12]. Finding of the new compound is one of the tough tasks but research efforts at the National Institute of Allergy and Infectious Diseases has recognize a screening program, to find out the new compounds that are actively used against $M$. tuberculosis [13]. The purpose of this review is to gather the literature as well as to know the phytochemical and pharmacological effects of medicinal plants which may be helpful in the treatment of tuberculosis.

\section{Methodology}

The current review contains the published data of medicinal plants having antibacterial (antituberculosis) activity. Information of medicinal plants were collected by using various search engines (Google scholar, PubMed and scopus).

\section{Discussion}

Medicinal plants are used from the ancient times in the treatment of various diseases. These plants are wild or cultivated which contain various therapeutic agents having various pharmacological activities [16]. Table 1 consist of 
botanical name, family, parts used, plant extracts, pathogens, minimum inhibitory concentration (MIC) $(\mathrm{mg} / \mathrm{ml})$, zone of inhibition (mm), traditional uses and the methods used for determination of antibacterial activity. These study explained medicinal plants used for treating tuberculosis. While Table 2 comprises the vernacular name, family, concentration, parts used, extracts and toxic effects on the tested animals.

The antibacterial activity (antituberculosis) of these plants are due to their metabolites such as phenol, glycosides, alkaloids, steroids, tannins, terpenes, trepenoids, saponins and flavonoids.

Medicinal plants are used in the different dosage form like decoction, concoction, tablets, capsule and syrup. Decoction and extract of the plants are the common technique used due to easy intake [17].

\section{Antibacterial effects of some medicinal plants used in the treatment of tuberculosis}

Incidence of tuberculosis increases due to multiple drug resistance and HIV infected patients [18]. Traditionally, many plants has been used for the treatment of tuberculosis. These plants contain active biomolecules having antimycobacterial activity. Furthermore, these plants decreased the adverse effects as well as multi-drug resistance [19].

There are four plants such as Allium sativum L. and Aloe vera (L.) Burm.f., Acalypha indica L., and Allium cepa L., leaves and bulbs have antibacterial activity against M. tuberculosis. The extracts of the plants were taken in concentration from $0.02-0.04 \mathrm{mg} / \mathrm{ml}$. The zone of inhibition against the MBT were between 2.5 and $17.3 \mathrm{~mm}$. A. indica showed strong inhibiting activity $(17.3 \mathrm{~mm})$ against $\mathrm{H} 37 \mathrm{Rv}$ strain of $\mathrm{M}$. tuberculosis by using L-J proportion method [20].

Traditionally P. granatum (L.), Artemisia afra Jacq. Ex Willd, Abutilon indicum (L.), Carica papaya (L.), Bombax ceiba (L.), Linum usitatissimum L., Aegle marmelos (L.), and Bauhinia variegate (L.) are used against tuberculosis. However, few medicinal plants have been investigated properly for their therapeutic effects against tuberculosis.

Table 1: In-vitro activity of some medicinal plants having antituberculosis effects.

\begin{tabular}{|c|c|c|c|c|c|c|c|c|c|}
\hline Plant name & Reference & Part used & Extract & Pathogenic agent & $\begin{array}{c}\text { Concentration } \\
(\mathrm{mg} / \mathrm{ml})\end{array}$ & $\begin{array}{l}\text { Inhibition } \\
(\mathrm{mm})\end{array}$ & $\begin{array}{c}\text { MIC (mg/ } \\
\mathrm{ml})\end{array}$ & Traditional uses & Method \\
\hline Allium sativum (L) & Amaryllidaceae & Bulb & $\begin{array}{l}\text { Water, } \\
\text { Crude } \\
\text { extract }\end{array}$ & $\begin{array}{c}\text { Mycobacterium } \\
\text { tuberculosis (H37Rv } \\
\text { strain)c }\end{array}$ & $\begin{array}{l}0.02 \\
0.04\end{array}$ & $\begin{array}{c}10.92 \\
16.0\end{array}$ & $\mathrm{~N} / \mathrm{A}$ & Tuberculosis & $\begin{array}{l}\text { Lowenstein } \\
\text { Jensen proportion } \\
\text { method. }\end{array}$ \\
\hline Aloe vera $(\mathrm{L})$ & Asphodelaceae & $\begin{array}{c}\text { Leave, } \\
\text { Leave gel }\end{array}$ & $\begin{array}{l}\text { Pure gel, } \\
\text { Ethanol } \\
\text { acetone }\end{array}$ & $\begin{array}{c}\text { Mycobacterium } \\
\text { tuberculosis (H37Rv } \\
\text { strain) }\end{array}$ & $\begin{array}{l}0.02 \\
0.04\end{array}$ & $\begin{array}{c}2.54 \\
10.41\end{array}$ & $\mathrm{~N} / \mathrm{A}$ & Tuberculosis & $\begin{array}{l}\text { L-J proportion } \\
\text { method }\end{array}$ \\
\hline Acalypha indica (L) & Euphorbiaceae & Leaves & $\begin{array}{l}\text { Water } \\
\text { extract, }\end{array}$ & $\begin{array}{c}\text { Mycobacterium } \\
\text { tuberculosis (H37Rv } \\
\text { strain) }\end{array}$ & $\begin{array}{l}0.020 \\
0.040\end{array}$ & $\begin{array}{l}12.7 \\
17.3\end{array}$ & $\mathrm{~N} / \mathrm{A}$ & TB & $\begin{array}{l}\text { L-J proportion } \\
\text { method }\end{array}$ \\
\hline Allium cepa (L) & Liliaceae & Bulb & Aqueous & $\begin{array}{l}\text { Mycobacterium } \\
\text { tuberculosis }\end{array}$ & $\begin{array}{l}0.02 \\
0.04\end{array}$ & $\begin{array}{l}9.9 \\
8.9\end{array}$ & $\mathrm{~N} / \mathrm{A}$ & Tuberculosis & $\begin{array}{l}\text { L-J proportion } \\
\text { method }\end{array}$ \\
\hline
\end{tabular}

Table 2: Toxicity of medicinal plants used traditionally for the treatment of tuberculosis.

\begin{tabular}{|c|c|c|c|c|c|c|c|}
\hline S.No & Plant Name/ Rf.no & Family & Concentration & Part used & Extract & Toxic effect & Test Animal \\
\hline 1 & $\begin{array}{l}\text { Acorus calamus }(\mathrm{L}) \\
{[30]}\end{array}$ & Acoraceae & 100 & Rhizome & Acetone & Haemolysis & Sheep \\
\hline 2 & $\begin{array}{l}\text { Curcuma longa }(L) \\
{[27,28]}\end{array}$ & Zingiberaceae & $\begin{array}{l}1000 \\
0.1\end{array}$ & $\begin{array}{l}\text { Rhizome } \\
\text { Root }\end{array}$ & $\begin{array}{l}\text { Hydro alcohol } \\
\text { Root extract }\end{array}$ & $\begin{array}{l}\text { Mild depression, reduced } \\
\text { respiration, dullness } \\
\text { Apoptosis, To stop the } \\
\text { development of embryo at } \\
\text { the morula stage. }\end{array}$ & $\begin{array}{c}\text { Rat } \\
\text { Rabbit }\end{array}$ \\
\hline 3 & $\begin{array}{l}\text { Ephedra gerardiana } \\
\qquad[29]\end{array}$ & Ephedraceae & Excess amount & Herb & Alkaloid & $\begin{array}{l}\text { High blood pressure, heart } \\
\text { problem and liver damage, }\end{array}$ & Human \\
\hline 4 & $\begin{array}{l}\text { Glycyrrhiza glabra (L) } \\
\text { [26] }\end{array}$ & Fabaceae & $\begin{array}{l}\text { Excess amount } \\
760-2,280\end{array}$ & $\begin{array}{c}\text { Root } \\
\text { Dried root }\end{array}$ & $\begin{array}{l}\text { Glycyrrhizinic Acid } \\
\text { Glycyrrhizinic Acid }\end{array}$ & $\begin{array}{l}\text { Blood pressure, kidney, } \\
\text { edema and hypertension. } \\
\text { Hypokalemia, edema. }\end{array}$ & $\begin{array}{l}\text { Human } \\
\text { Human }\end{array}$ \\
\hline 5 & $\begin{array}{c}\text { Hygrophila auriculata } \\
\text { [32-33] }\end{array}$ & Acanthaceae & $\begin{array}{c}80 \\
1.1-1.6 \\
0.22 \\
2000\end{array}$ & $\begin{array}{l}\text { Seed } \\
\text { Leaves }\end{array}$ & $\begin{array}{c}\text { Gentamicin } \\
\text { Methanol } \\
\text { Aqueous } \\
\text { Methanolic extract }\end{array}$ & $\begin{array}{l}\text { Cytotoxicity } \\
\text { Dehydration }\end{array}$ & $\begin{array}{l}\text { Human cancer cell lines (Breast, } \\
\qquad \text { Colon) } \\
\text { Albino rat }\end{array}$ \\
\hline 6 & $\begin{array}{l}\text { Papaver somniferum (L) } \\
\text { [31] }\end{array}$ & Papaveraceae & 150 & $\begin{array}{l}\text { Stem } \\
\text { Root }\end{array}$ & Ethyl acetate & Necrotic effect & $\begin{array}{l}\text { African green monkey kidney, human } \\
\text { colorectal adenocarcinoma, rat } \\
\text { brain tumour cells and human cervix } \\
\text { carcinoma. }\end{array}$ \\
\hline
\end{tabular}

Citation: Hussain A, Ali AA, Ayaz S, Wahidullah, Mehar P, et al. (2021) Anti-tuberculosis effects of different medicinal plants: A narrative review. Open J Plant Sci 


\section{Toxicity of some medicinal plants used in the treatment of tuberculosis}

Medicinal plants contain primary and secondary metabolite called bioactive natural products. These metabolites have various pharmacological activities and used for the treatment of different diseases. However toxic effects may be observed in the use of various plants [21-24].

It is believed that herbal medicines are safe, but this review reported seven medicinal plants having toxic effects in human beings and animals [25].

It has been reported that G. glabra contain glycyrrhizin and glycyrrhizinic acid. These chemical constituents stimulate the excretion of adrenal cortex hormones (Mineralocorticoid). The increase level of mineralocorticoid decreases renin level, sodium retention, hypokalemia, hypervolemia, edema and hypertension. Furthermore, it has been observed that glycyrrhiza glabra is harmful for the people having high blood pressure, heart and kidney diseases [26].

$1000 \mathrm{mg} / \mathrm{kg}$ of hydroalcoholic extract of C. longa induces depression and decreased respiration. Furthermore, root extract of C. longa $(0.1 \mu \mathrm{g} / \mathrm{ml})$ stops the growth of embryo in rabbit at morula stage $[27,28]$.

George P conducted a study in 2011, which explained that excessive amount of Ephedra gerardiana causes liver damage, heart problem, high blood pressure [29].

Ahmad et al., explained a study that acetone extract of Acorus calamus causes hemolysis [30]. Papaver somniferum is a good source of different bioactive molecules and used for many diseases but it has necrotic effects at concentration of 150 $\mu \mathrm{g} / \mathrm{ml}$ [31]. Seeds and leaves extract of Hygrophila auriculata in various solvents exhibit cytotoxicity and dehydration effects in albino rat [32,33] Table 2.

\section{Conclusions}

Medicinal plants contain most of the bioactive natural compounds that exhibit various pharmacological activities. The current study explained that some of medicinal plants are traditionally used in the treatment of TB. Leaves and bulbs are the common parts used in the form of extract and decoction. While some of the plants have potential effects against tuberculosis but they produce toxic effects in the body.

\section{References}

1. Jones RN (2010) Microbial etiologies of hospital-acquired bacterial pneumonia and ventilator-associated bacterial pneumonia. Clin Infect Dis 51: 81-87. Link: https://bit.ly/2WtEb3e

2. Cilloniz C, Martin-Loeches I, Garcia-Vidal C, San Jose A, Torres A, et al. (2016) Microbial etiology of pneumonia, epidemiology, diagnosis and resistance patterns. Int J Mol Sci 17: 2120. Link: https://bit.ly/3kSBbGP

3. WHO (2008) Global tuberculosis control: Surveillance, planning and financing, WHO report. Geneva, Switzerland: WHO. Link: https://bit.ly/3uujyjR

4. Wejse C, Gustafson P, Nielsen J, Gomes VF, Aaby P, et al. (2008) TBscore Signs and symptoms from tuberculosis patients in a low-resource setting have predictive value and may be used to assess clinical course. Scand $J$ Infect Dis 2008: 111-120. Link: https://bit.ly/39SskPm

5. Wechsler H, Westfall M, Lattimer JK (1960) The earliest signs and symptoms in 127 male patients with genitourinary tuberculosis. J Urol 83: 801-803. Link: https://bit.ly/39PFAUL

6. Rai S, Thomas WM (2003) Diagnosis of abdominal tuberculosis: the importance of laparoscopy. J R Soc Med 96: 586-588. Link: https://bit.ly/2WrShSL

7. Marais BJ, Pai M (2007) Recent advances in the diagnosis of childhood tuberculo-sis. Arch Dis Child 92: 446-452. Link: https://bit.ly/3zPYNQV

8. Singh IP, Bharate SB, Bhutani KK (2005) Anti-HIV natural products. Curr Sci 89 269-290. Link: https://bit.ly/3uq2yLG

9. Amber R, Adnan M, Tariq A, Mussarat S (2016) A review on antiviral activity of the Himalayan medicinal plants traditionally used to treat bronchitis and related symptoms. J Pharm Pharmacol 69: 1-14. Link: https://bit.ly/3AV32vG

10. Chaisson RE, Slutkin G (1989) Tuberculosis and human immunodeficiency virus infection. Journal of infectious diseases 159: 96-100.

11. Harries AD (1990) Tuberculosis and human immunodeficiency virus infection in developing countries. Lancet 335: 387-390. Link: https://bit.ly/3mbAI7D

12. Telzak EE (1997) Tuberculosis and human immunodeficiency virus infection. Medical Clinics of North America 81: 345-360.

13. De Cock KM, Chaisson RE (1999) Will DOTS do it? A reappraisal of tuberculosis control in countries with high rates of HIV infection. Int $\mathrm{J}$ Tuberc Lung Dis 3 : 457-465. Link: https://bit.ly/39QUREN

14. Program TDS (2001) Search for new drugs for treatment of tuberculosis. Antimicrob Agents Chemother 45: 1943-1946. Link: https://bit.ly/3AVqDfH

15. Sheng-Ji P (2001) Ethnobotanical approaches of traditional medicine studies, some experiences from Asia. Pharm Biol 39: 74-79. Link: https://bit.ly/3zUZYyt

16. Prakash R (2015) Medicinal plants used by tribal communities: a study of Uttarakhand himalayan region. Int J Humanit Soc Sci Invent 4: 55-61. Link: https://bit.ly/3ikHMZf

17. Shah AS, Rahim S, Bhatti KH, Khan A, Din N, et al. (2015) Ethnobotanical study and conservation status of trees in the district Sargodha, Punjab, Pakistan. Int J Exp Bot 84: 34-44. Link: https://bit.ly/3kSeXF5

18. Hingley-Wilson SM, Sambandamurthy VK, Jacobs WR (2003) Survival perspectives from the world's most successful pathogen, Mycobacterium tuberculosis. Nat Immunol 4: 949. Link: https://go.nature.com/3uu35wi

19. Sharifi-Rad J, Salehi B, Stojanović-Radić ZZ, Fokou PVT, Sharifi-Rad M, et al. (2020) Medicinal plants used in the treatment of tuberculosis-Ethnobotanical and ethnopharmacological approaches. Biotechnol Adv 107629. Link: https://bit.ly/3A05Lm9

20. Gupta R, Thakur B, Singh P, Singh HB, Sharma VD, et al. (2010) Antituberculosis activity of selected medicinal plants against multi-drug resistant Mycobacterium tuberculosis isolates. Indian J Med Res 131: 809-813. Link: https://bit.ly/3kUmy65

21. Al-Qura'n S (2005) Ethnobotanical survey of folk toxic plants in southern part of Jordan. Toxicon 46: 119-129. Link: https://bit.ly/3zVb5aw

22. Maiga A, Diallo D, Fane S, Sanogo R, Paulsen BS, et al. (2005) A survey of toxic plants on the market in the district of Bamako, Mali: traditional knowledge compared with a literature search of modern pharmacology and toxicology. $J$ Ethnopharmacol 96: 183-193. Link: https://bit.ly/3omXOFE

23. Schultes RE, Raffauf RF (1990) The healing forest: medicinal and toxic plants of the Northwest Amazonia. Dioscorides press.

Citation: Hussain A, Ali AA, Ayaz S, Wahidullah, Mehar P, et al. (2021) Anti-tuberculosis effects of different medicinal plants: A narrative review. Open J Plant Sci 
24. Burrows GE, Tyrl RJ (2013) Toxic plants of north America. John Wiley \& Sons Link: https://bit.ly/3il6Wqu

25. George P (2011) Concerns regarding the safety and toxicity of medicinal plants - an overview. J Appl Pharm Sci 1: 40-44. Link: https://bit.ly/3op4oeK

26. Roshan A, Verma NK, Kumar CS, Chandra V (2012) Phytochemical constituents, pharmacological activities and medicinal uses through the millenia of Glycyrrhiza glabra a review. Int Res J Pharm 3: 45-55. Link: https://bit.ly/3ofOhjl

27. Govind $P$ (2011) Active principles and median lethal dose of Curcuma longa Linn. Int J Res Pharm 2: 239-241. Link: https://bit.ly/3F35B1I

28. Foldesiova M, Balážl $A$, Chrenek P (2016) The effect of Curcuma longa plant extract on the rabbit embryo development in vitro. Slovak J Anim Sci 49: 132136. Link: https://bit.ly/3kUpjUT
29. George $P$ (2011) Concerns regarding the safety and toxicity of medicinal plants - an overview. J Appl Pharm Sci 1: 40-44. Link: https://bit.ly/3op4oeK

30. Ahmad I, Aqil F (2007) In vitro efficacy of bioactive extracts of 15 medicinal plants against ESbL-producing multidrug-resistant enteric bacteria. Microbiol Res 162: 264-275. Link: https://bit.ly/3AWNuaU

31. World Cancer Report (2014) WHO. Link: https://bit.ly/390D15k

32. Shaikh J, Grice ID Tiralongo E (2011) Cytotoxic effects of Bangladeshi medicinal plant extracts. Evid Based Complement Alternat Med 2011: 578092 Link: https://bit.ly/3mftPfY

33. Vishnu N, Kshirsagar S, Pandhare R (2015) Acute toxicity study of Hygrophila auriculata $\mathrm{L}$. leaves methanolic extract in albino rats. J Pharm Chem Bio Sci 3 : 388-395. Link: https://bit.ly/3CTH7FM
Discover a bigger Impact and Visibility of your article publication with

\section{Peertechz Publications}

\section{Highlights}

* Signatory publisher of ORCID

* Signatory Publisher of DORA (San Francisco Declaration on Research Assessment)

* Articles archived in worlds' renowned service providers such as Portico, CNKI, AGRIS, TDNet, Base (Bielefeld University Library), CrossRef, Scilit, J-Gate etc.

* Journals indexed in ICMJE, SHERPA/ROMEO, Google Scholar etc.

* OAI-PMH (Open Archives Initiative Protocol for Metadata Harvesting)

* Dedicated Editorial Board for every journa

* Accurate and rapid peer-review process

* Increased citations of published articles through promotions

* Reduced timeline for article publication

Submit your articles and experience a new surge in publication services (https://www.peertechz.com/submission). 